ARTICLE

\title{
The stability of subducted glaucophane with the Earth's secular cooling
}

Yoonah Bang (1) 1, Huijeong Hwang (1) 1, Taehyun Kim (10) 1, Hyunchae Cynn (1) 2, Yong Park (1) ${ }^{3}$, Haemyeong Jung (10 ${ }^{3}$, Changyong Park (1) ${ }^{4}$, Dmitry Popov ${ }^{4}$, Vitali B. Prakapenka (i) ${ }^{5}$, Lin Wang ${ }^{6}$, Hanns-Peter Liermann (10 ${ }^{7}$, Tetsuo Irifune ${ }^{8}$, Ho-Kwang Mao ${ }^{6} \&$ Yongjae Lee ${ }^{1 凶}$

The blueschist to eclogite transition is one of the major geochemical-metamorphic processes typifying the subduction zone, which releases fluids triggering earthquakes and arc volcanism. Although glaucophane is an index hydrous mineral for the blueschist facies, its stability at mantle depths in diverse subduction regimes of contemporary and early Earth has not been experimentally determined. Here, we show that the maximum depth of glaucophane stability increases with decreasing thermal gradients of the subduction system. Along cold subduction geotherm, glaucophane remains stable down ca. $240 \mathrm{~km}$ depth, whereas it dehydrates and breaks down at as shallow as ca. $40 \mathrm{~km}$ depth under warm subduction geotherm or the Proterozoic tectonic setting. Our results imply that secular cooling of the Earth has extended the stability of glaucophane and consequently enabled the transportation of water into deeper interior of the Earth, suppressing arc magmatism, volcanism, and seismic activities along subduction zones.

\footnotetext{
${ }^{1}$ Department of Earth System Sciences, Yonsei University, Seoul, South Korea. ${ }^{2}$ Physics Division, Physical and Life Sciences Directorate, Lawrence Livermore National Laboratory, Livermore, CA, USA. ${ }^{3}$ School of Earth and Environmental Sciences, Seoul National University, Seoul, South Korea. ${ }^{4}$ High Pressure Collaborative Access Team, X-ray Science Division, Argonne National Laboratory, Argonne, IL, USA. ${ }^{5}$ Center for Advanced Radiation Sources, University of Chicago, Argonne, IL, USA. ${ }^{6}$ Center for High Pressure Science \& Technology Advanced Research, Shanghai, China. ${ }^{7}$ Photon Sciences, Deutsches ElektronenSynchrotron (DESY), Hamburg, Germany. ${ }^{8}$ Geodynamics Research Center, Ehime University, Matsuyama, Ehime, Japan. ${ }^{凶}$ email: yongjaelee@yonsei.ac.kr
} 
P late tectonics such as subduction has been operating since the early Earth ${ }^{1-6}$, possibly since the Hadean or Eoarchean ${ }^{7}$. The Archean mantle temperature is estimated to be ca. $1500-1650{ }^{\circ} \mathrm{C}$, which is higher than the present mantle temperatures of ca. $1350 \pm 50^{\circ} \mathrm{C}$ (refs. ${ }^{8,9}$ ). Thus, geothermal gradients in the Archean are similar or even higher than those of modern-day warm subduction zones $\left(\sim 8-12^{\circ} \mathrm{C} \mathrm{km}^{-1}\right)^{2-4}$. Under the $\mathrm{P}-\mathrm{T}$ conditions of warm subduction, oceanic crust may release twothirds of its water $<2 \mathrm{GPa}$, equivalent to $\sim 60 \mathrm{~km}$ depth, while still delivering ca. 2 wt. $\% \mathrm{H}_{2} \mathrm{O}$ to the deeper Earth ${ }^{10-12}$. On the other hand, the Earth has undergone secular cooling from $2.5-3.0 \mathrm{Ga}$ ago by as much as $50-100^{\circ} \mathrm{C} \mathrm{Ga}^{-1}$ over the last $3 \mathrm{Ga}$, while $100-150^{\circ} \mathrm{C} \mathrm{Ga}^{-1}$ in the present because the surface heat loss exceeded internal heating ${ }^{9,13}$. In turn, such a cooling in the average mantle temperature has affected the tectonic processes of the Earth by facilitating the modern-style subduction with low thermal gradient slabs $\left(\sim 5-8^{\circ} \mathrm{C} \mathrm{km}^{-1}\right)^{13-16}$. These cold subduction zones may allow the oceanic crust to lose only about onethird of its water by $2 \mathrm{GPa}$ or $\sim 60 \mathrm{~km}$ depth ${ }^{10-12}$, hence transport more water into the deeper Earth. The water (or fluid) released from subducting slabs buoyantly rises in the overlying mantle wedge or crust to lower the solidus temperature by ca. $200-400{ }^{\circ} \mathrm{C}$ inducing partial melting and volcanism ${ }^{17,18}$. The $\mathrm{H}_{2} \mathrm{O}$ transport into the deep Earth is realized by subducting hydrous minerals, which exhibit a range of stability dictated by the P-T regime of the subduction system ${ }^{10,11,19}$. It is therefore essential to investigate the stability of hydrous minerals as a function of diverse geothermal gradients in the past and present tectonic settings to fully understand the evolution of deep water cycling, and related geochemical and geophysical activities.

The major fluid carriers in subducting oceanic crust are hydrous minerals, such as lawsonite, chlorite, and amphiboles, where $\mathrm{H}_{2} \mathrm{O}$ is contained in the form of molecules and/or structural hydroxyl ${ }^{20}$. Lawsonite $\left(\mathrm{CaAl}_{2} \mathrm{Si}_{2} \mathrm{O}_{7}(\mathrm{OH})_{2} \cdot \mathrm{H}_{2} \mathrm{O}\right)$ contains as much as ca. 11.2 wt. $\% \mathrm{H}_{2} \mathrm{O}$ in both molecular and hydroxyl forms, whereas structural hydroxyls account for ca. 10-13 wt.\% $\mathrm{H}_{2} \mathrm{O}$ in chlorites $\left((\mathrm{Mg}, \mathrm{Fe})_{5} \mathrm{Al}_{2} \mathrm{Si}_{3} \mathrm{O}_{10}(\mathrm{OH})_{8}\right)$. Amphiboles carry ca. 1-3 wt.\% $\mathrm{H}_{2} \mathrm{O}$, much smaller than that of lawsonite or chlorite, but represent the greatest $\mathrm{H}_{2} \mathrm{O}$ sink because amphiboles may account for a large portion of the metamorphosed oceanic crust by as much as 20-60 wt.\% for basaltic (MORB) compositions ${ }^{21}$. Glaucophane $\left(\mathrm{Na}_{2}(\mathrm{Mg}, \mathrm{Fe})_{3} \mathrm{Al}_{2} \mathrm{Si}_{8} \mathrm{O}_{22}(\mathrm{OH})_{2}\right)$ is a sodic amphibole (Supplementary Fig. 1 and Supplementary Table 1), diagnostic for the blueschist facies together with either lawsonite or epidote. The role of amphiboles in basaltic slabs for the generation of arc magma has been experimentally studied for decades to determine whether and how the dehydration of amphiboles provides water to the overlying mantle wedge $\mathrm{e}^{22}$. Such dehydration reactions responsible for the blueschist to eclogite transition indeed release a considerable amount of $\mathrm{H}_{2} \mathrm{O}$, which triggers intermediate-depth earthquakes via the dehydration embrittlement ${ }^{23-25}$ and induces partial melting in the overlying mantle wedge leading to arc magmatism ${ }^{18,26}$. In general, the blueschist to eclogite transition is characterized by a suite of dehydration reactions involving the breakdown of amphiboles into pyroxenes $^{27,28}$, and lawsonite into the garnet-kyanite-coesite assemblage $^{29}$ at elevated P-T conditions ${ }^{27,30}$. The so-called "absence of blueschist" is thus linked to the global dehydration and breakdown of the blueschist in the Precambrian plate tectonic settings, where warm subduction was a predominant process for recycling of $\mathrm{H}_{2} \mathrm{O}$ (ref. ${ }^{31}$ ).

In order to understand the present-day subduction process of oceanic crust and gain insights into the evolution of deep water cycle as a function of the Earth's secular cooling, we have investigated the stability of glaucophane under P-T conditions mimicking cold and warm subduction geotherms together with the high thermal gradients for the Proterozoic tectonic setting ${ }^{3}$ (Fig. 1 and see "Methods" section in Supplementary information). Using the thermal models of global subduction system ${ }^{19}$, our experimental P-T conditions followed the geotherms of the North Cascadia and South Chile subduction zones, and the Tonga and Kermadec subduction zones, representing warm and cold subduction systems, respectively. The Proterozoic thermal gradients of $25-50{ }^{\circ} \mathrm{C} \mathrm{km}^{-1}$ in $\delta T / \delta$ Depth were based on the recent compilation of $\mathrm{P}-\mathrm{T}$ data estimated from 456 localities encompassing the Eoarchean to Cenozoic Eras ${ }^{3}$. We have used both resistive-heated and laser-heated (LH) diamond-anvil cell (DAC) techniques for in situ and ex situ high-pressure and hightemperature (HP-HT) synchrotron X-ray powder diffraction (XRD) experiments up to 7.8(3) $\mathrm{GPa}$ and $1390 \pm 30^{\circ} \mathrm{C}$. We have also utilized a Paris-Edinburgh cell (PEC) ${ }^{32}$ to perform in situ reversal experiments on a mixture of reactants containing glaucophane and a 1000-ton multi-anvil press to retrieve the dehydration products of glaucophane from $3 \mathrm{GPa}$ and $950 \pm 5^{\circ} \mathrm{C}$. A modified Griggs apparatus was also employed to extend the observation of glaucophane to a natural epidote blueschist rock up to $2 \mathrm{GPa}$ and $730 \pm 10^{\circ} \mathrm{C}$ condition. In order to ensure that our experiments represent equilibrium conditions, samples in DAC and large volume press runs were held at selected pressure and temperature conditions for $1 \mathrm{~h}$ or up to several hours. Here, we show that the dehydration of glaucophane strongly depends on the thermal gradients of the subduction zone, so that arc magmatism, volcanism, and seismic activities would have been suppressed by secular cooling and subsequent generation of cold subduction system, where water is transported deeper into the Earth.

\section{Results}

Stability of glaucophane along cold subduction zone. In situ HP-HT XRD experiments on glaucophane were performed up to 7.8(3) $\mathrm{GPa}$ and $760 \pm 45^{\circ} \mathrm{C}$ for the slab surface, and up to 5.6(3) $\mathrm{GPa}$ and $450 \pm 30^{\circ} \mathrm{C}$ for the slab Moho under dry and wet with 4 wt.\% of $\mathrm{H}_{2} \mathrm{O}$ conditions to follow the cold subduction geotherm of the Tonga and Kermadec thermal model ${ }^{19}$ (Fig. 1, Supplementary Fig. 2, and Supplementary Table 2). Glaucophane under such cold subduction geotherm conditions remained stable up to 7.6(3) $\mathrm{GPa}$ and $660 \pm 40^{\circ} \mathrm{C}$ conditions, equivalent to ca. $240 \mathrm{~km}$ depth. This extends the stability of glaucophane compared to 3.1 (1) $\mathrm{GPa}$ at $700 \pm 10^{\circ} \mathrm{C}$ or $2.5(1) \mathrm{GPa}$ at $840 \pm 10^{\circ} \mathrm{C}$, as estimated in previous studies ${ }^{33-35}$. Our result is in agreement with the estimation that oceanic crust within cold subduction zone holds more water by ca. 2 wt.\% than in warm subduction zone $e^{10-12}$. Subsequently, at higher pressure and temperature conditions of 7.8(3) $\mathrm{GPa}$ and $760 \pm 45^{\circ} \mathrm{C}$, equivalent to ca. $245 \mathrm{~km}$ depth, we found that glaucophane dehydrates and breakdowns into pyroxenes and coesite as described below (Fig. 2 and Supplementary Fig. 5):

$$
\begin{aligned}
& \mathrm{Na}_{2}(\mathrm{Mg}, \mathrm{Fe})_{3} \mathrm{Al}_{2} \mathrm{Si}_{8} \mathrm{O}_{22}(\mathrm{OH})_{2}=2 \mathrm{NaAlSi}_{2} \mathrm{O}_{6}+1.5\left(\mathrm{Mg}_{1-x} \mathrm{Fe}_{x}\right)_{2} \mathrm{Si}_{2} \mathrm{O}_{6}+\mathrm{SiO}_{2}+\mathrm{H}_{2} \mathrm{O} \\
& \text { Glaucophane Jadeite Enstatite Coesite Fluid }
\end{aligned}
$$

In order to confirm the enhanced stability and provide a link to interpret seismic low-velocity layer along cold subduction zones, we determined the bulk modulus and linear compressibility of glaucophane at ambient and high temperature at $620^{\circ} \mathrm{C}$ under diverse pressure media (Supplementary Fig. 4). Our derived bulk moduli are the same for the different pressure media within $2 \sigma$ and agree well with the data reported in previous studies ${ }^{36,37}$. We identify that under high-temperature conditions, the anisotropy in linear compressibility is significantly modulated, i.e., at ambient temperature, $\beta_{\mathrm{a}}=5.1\left(\mathrm{kbar}^{-1} \times 10^{-4}\right)$, while $\beta_{\mathrm{b}}=2.3$ 


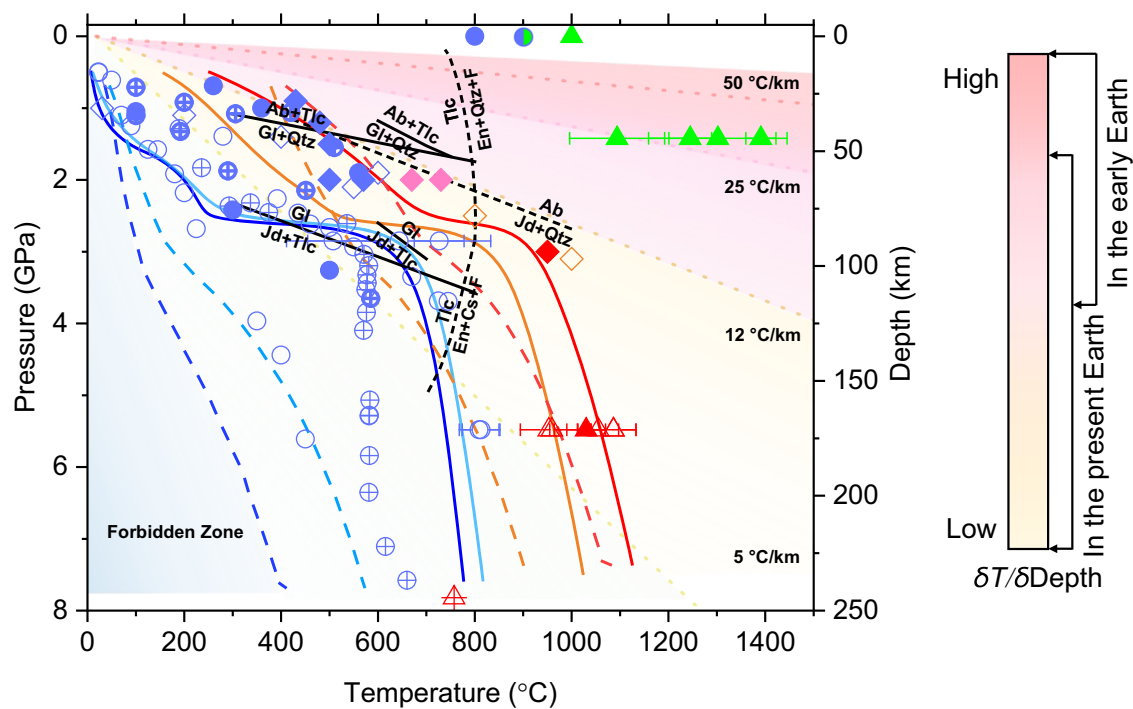

$\overline{---}$ Tonga
$\overline{---}$ Kermadec
$\overline{---}$ South Chile
$\overline{\overline{-}-\bar{N} \text { North Cascadia }}$
Slab surface (solid)
Slab Moho (dashed)
Thermal gradient (dot)
Reactions (black)

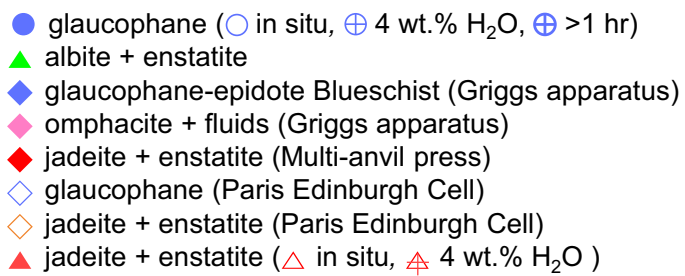

Fig. 1 Stability of glaucophane at P-T conditions of different subduction geotherms. Curved lines represent individual subduction geotherms from Syracuse et al. ${ }^{19}$. Continuous and dashed curves denote the P-T paths of subducting slab surfaces and corresponding slab Moho, respectively. The Tonga and Kermadec represent cold subducting slab, whereas the North Cascadia and South Chile represent warm subducting slabs. Black lines represent the upper- and lower-pressure stability of glaucophane from previous studies $33,34,39$, while black dashed lines represent related reactions $40,61-63$. The colored trilateral regions from top to bottom represent high, intermediate, and low geothermal gradients ( $\delta T / \delta$ Depth), as defined by Brown and Johnson ${ }^{3}$. The forbidden zone is a P-T region of ultrahigh pressures, where many numerical models predict slab-top geotherms of $<5^{\circ} \mathrm{C} \mathrm{km}{ }^{-1}\left(\mathrm{ref}^{64}\right)$. High-temperature experiments at ambient pressure were performed as a reference (Supplementary Fig. 9). Phase abbreviations: glaucophane (Gl), jadeite (Jd), enstatite $(E n)$, albite $(A b)$, talc $(T l c)$, quartz $(Q t z)$, coesite $(C s)$, and fluid $(F)$.

a

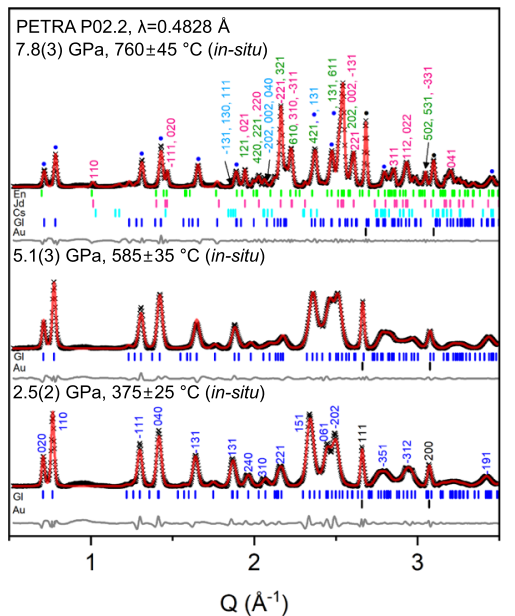

b

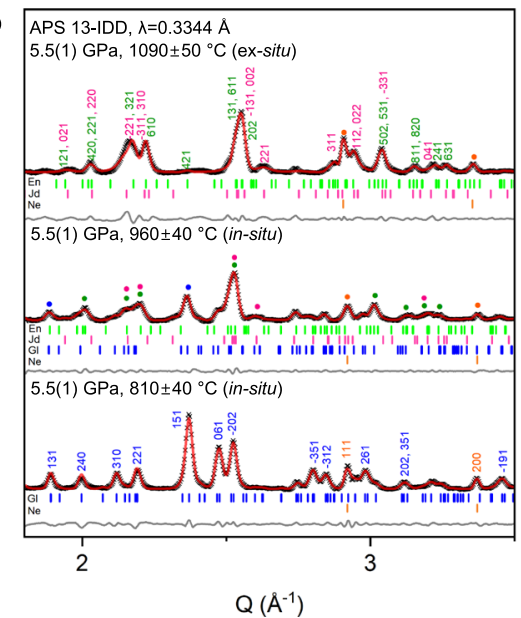

C

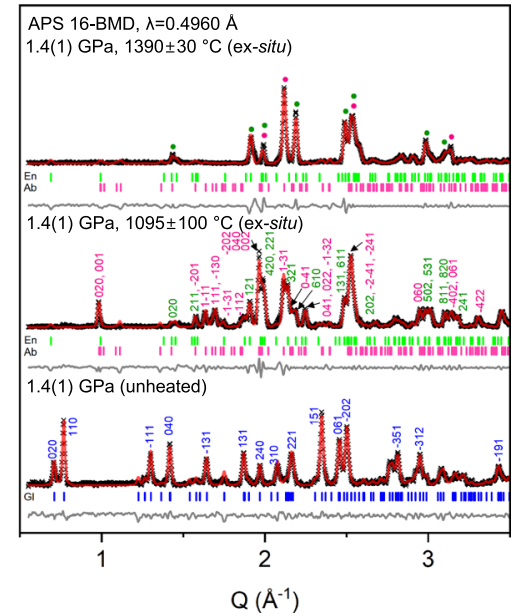

Fig. 2 XRD patterns of glaucophane at P-T conditions of three different subduction geotherms. Representative $X$-ray powder diffraction patterns of glaucophane along the P-T conditions of $\mathbf{a}$ cold subduction zone, $\mathbf{b}$ warm subduction zone, and $\mathbf{c}$ high thermal gradients in the Proterozoic tectonic settings. The experimental data and profile fits using the LeBail method 65,66 are shown in black symbols and red lines, respectively, with difference curves in gray lines. The backgrounds of the X-ray diffraction patterns have been subtracted prior to the data being fitted (see Supplementary Fig. 3 for the original patterns). Phase abbreviations: glaucophane (GI), enstatite (En), jadeite (Jd), albite (Ab), coesite (Cs), gold ( $\mathrm{Au}$ ), and neon ( $\mathrm{Ne})$. 
and $\beta_{\mathrm{c}}=2.2\left(\mathrm{kbar}^{-1} \times 10^{-4}\right)$, whereas at high temperature, the $a$-axis compressibility is reduced to $\beta_{\mathrm{a}}=3.9\left(\mathrm{kbar}^{-1} \times 10^{-4}\right)$, while $b$ - and $c$-axes compressibilities are maintained to $\beta_{\mathrm{b}}=2.3$ and $\beta_{\mathrm{c}}=2.4\left(\mathrm{kbar}^{-1} \times 10^{-4}\right)$, respectively.

Dehydration and breakdown of glaucophane along warm subduction zone. Ex situ and in situ HP-HT XRD experiments on glaucophane were performed up to 5.5(1) GPa and $1090 \pm 50^{\circ}$ $\mathrm{C}$ for the slab surface and up to $5.5(1) \mathrm{GPa}$ and $810 \pm 40^{\circ} \mathrm{C}$ for the slab Moho to follow the warm subduction geotherms of the North Cascadia and South Chile thermal models by Syracuse et al. ${ }^{19}$ (Fig. 1 and Supplementary Table 2). The XRD data of the quenched samples after heating at the slab surface conditions above ca. 5.5(1) $\mathrm{GPa}$ and $1090 \pm 50^{\circ} \mathrm{C}$, equivalent to $\mathrm{ca} .170 \mathrm{~km}$ depth, were indexed to identify the breakdown products of glaucophane as in Eq. (1) (Fig. 2 and Supplementary Fig. 5). The same dehydration scheme, though different in depths, under cold and warm subduction conditions agrees well with the thermodynamic calculation ${ }^{38}$. Structural hydroxyls of glaucophane are released as fluid when it decomposes into jadeite-bearing assemblages of the eclogite facies. Our experimental results thus demonstrate that blueschist to eclogite transition can be simulated by the dehydration breakdown of glaucophane at different depths depending on the subduction geotherms.

In order to complement our experimental results using a single mineral phase in a DAC, we have further investigated the dehydration of glaucophane on a macroscopic scale using a natural epidote blueschist rock containing ca. 55 vol.\% glaucophane. A $3 \mathrm{~mm}$ diameter core-drilled sample of blueschist rocks were heated up to $730 \pm 10^{\circ} \mathrm{C}$ at $2 \mathrm{GPa}$ for $9 \mathrm{~h}$, using a modified Griggs apparatus (Fig. 1 and Supplementary Table 2). The recovered sample showed that glaucophane has partially been dehydrated, and a new dehydration product, omphacite pyroxene $\left((\mathrm{Ca}, \mathrm{Na})(\mathrm{Mg}, \mathrm{Fe}, \mathrm{Al}) \mathrm{Si}_{2} \mathrm{O}_{6}\right)$, has formed, leaving trails of fluid inclusions in glaucophane crystals (Fig. 3 and Supplementary Fig. 7). Energy-dispersive spectroscopy confirmed the compositions of the recovered glaucophane and the new dehydration product omphacite, as shown in Supplementary Fig. 7. This result establishes that the dehydration of glaucophane in a natural blueschist rock begins near $670 \pm 10^{\circ} \mathrm{C}$ at $2 \mathrm{GPa}$ conditions, which corresponds to ca. $60 \mathrm{~km}$ depth along warm subduction zone.

Furthermore, we have carried out reversal experiments along the $\mathrm{P}-\mathrm{T}$ conditions of the warm subduction zones using a mixture of reactant minerals, i.e., glaucophane, jadeite, and talc, in the PEC. The mixture was heated above the breakdown condition of glaucophane up to $1000 \pm 100^{\circ} \mathrm{C}$ at 3.1(3) $\mathrm{GPa}$ over $4 \mathrm{~h}$, and then cooled down to $550 \pm 100^{\circ} \mathrm{C}$ at 2.1(3) $\mathrm{GPa}$ over $6 \mathrm{~h}$. At these $\mathrm{P}-\mathrm{T}$ conditions, we observed the regrowth of glaucophane (130) peak, attesting the reaction boundary would be between ca. 50 and $100 \mathrm{~km}$ depths along the warm subduction geotherms (Supplementary Fig. 8).

Subducting glaucophane in the high thermal gradients of the early tectonic setting. Additional LH-DAC experiments were conducted to mimic the high thermal gradients model in the Proterozoic tectonic setting. At conditions of 1.4(1) GPa after heating between $1095 \pm 100$ and $1390 \pm 30^{\circ} \mathrm{C}$, corresponding to a depth around $\sim 40 \mathrm{~km}$, glaucophane breaks down to albite and enstatite, and releases fluid $\mathrm{H}_{2} \mathrm{O}$ (ref. ${ }^{39}$; Fig. 2 and Supplementary Fig. 5), giving rise to the breakdown scheme:

$$
\underset{\text { Glaucophane }}{\mathrm{Na}_{2}(\mathrm{Mg}, \mathrm{Fe})_{3} \mathrm{Al}_{2} \mathrm{Si}_{8} \mathrm{O}_{22}(\mathrm{OH})_{2}} \rightarrow \underset{\text { Albite }}{\mathrm{NaAlSi}_{2} \mathrm{O}_{6}}+\underset{\text { Enstatite }}{\left(\mathrm{Mg}_{1-x} \mathrm{Fe}_{x}\right)_{2} \mathrm{Si}_{2} \mathrm{O}_{6}}+\underset{\text { Fluid }}{\mathrm{H}_{2} \mathrm{O}}
$$

This scheme is different from the Eq. (1) observed for the cold and warm subduction zones, but in the P-T relationship of the reaction, albite $=$ jadeite + quartz, albite is known to be stable at lower pressures than jadeite ${ }^{40}$. The onset depth of dehydration breakdown of glaucophane thus appears to be inversely proportional to the thermal gradients ( $\delta T / \delta$ Depth) of the subduction system. We, however, note that the established depths for the dehydration could change when reaction rates are considered, which is beyond our current experimental capability. Johnson and Fegley reported that partial dehydration can be initiated in amphibole tremolite over several months at temperatures between 750 and $965^{\circ} \mathrm{C}$ (refs. ${ }^{41,42}$ ).

\section{Discussion}

At the same depth, temperature difference between cold and warm subduction zones ranges from ca. $175^{\circ} \mathrm{C}$ to ca. $400^{\circ} \mathrm{C}$. According to the P-T conditions studied here (up to $7.8(3) \mathrm{GPa}$ and $760 \pm 45^{\circ} \mathrm{C}$ ), glaucophane would persist to depths of ca. $240 \mathrm{~km}$ in cold subduction zones with a geothermal gradient of $\sim 5-8{ }^{\circ} \mathrm{Ckm}^{-1}$. Along such cold subduction zones, the fully hydrated oceanic crust with the initial $\mathrm{H}_{2} \mathrm{O}$ content of ca. 6 wt.\% may lose ca. 2 wt. $\% \mathrm{H}_{2} \mathrm{O}$ by $2 \mathrm{GPa}$ or $\sim 60 \mathrm{~km}$ depth, while the rest would be transported deeper into the Earth ${ }^{10-12}$. This is in line
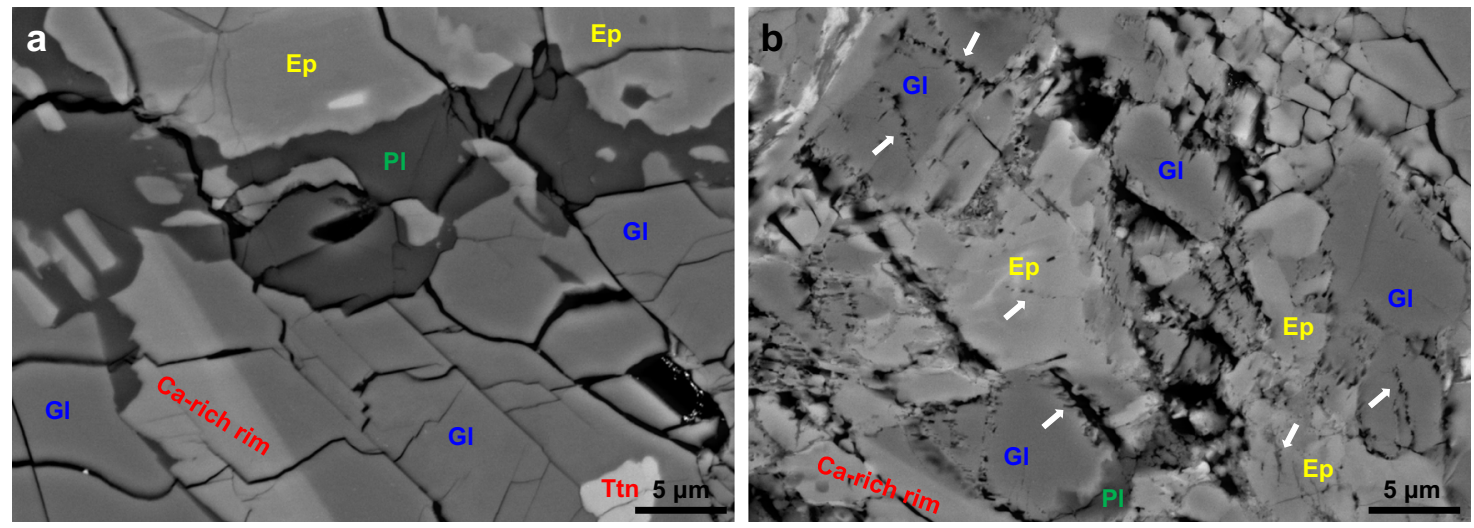

Fig. 3 Experimental product of natural epidote blueschist showing dehydration features of glaucophane. A modified Griggs apparatus was used for the dehydration of the natural epidote blueschist. Back-scattered electron (BSE) images showing a no dehydration of epidote blueschist after experiment at 2 $\mathrm{GPa}$ and $570 \pm 10^{\circ} \mathrm{C}$ and $\mathbf{b}$ partially dehydrated glaucophane (GI) with rugged grain boundaries and fluid inclusion trails (white arrows) after experiment at $2 \mathrm{GPa}$ and $730 \pm 10^{\circ} \mathrm{C}$; consequently, omphacite (om) has formed as the dehydration product (Supplementary Fig. 7). Phase abbreviations: epidote (Ep), plagioclase $(\mathrm{PI})$, and titanite (Ttn). 
a

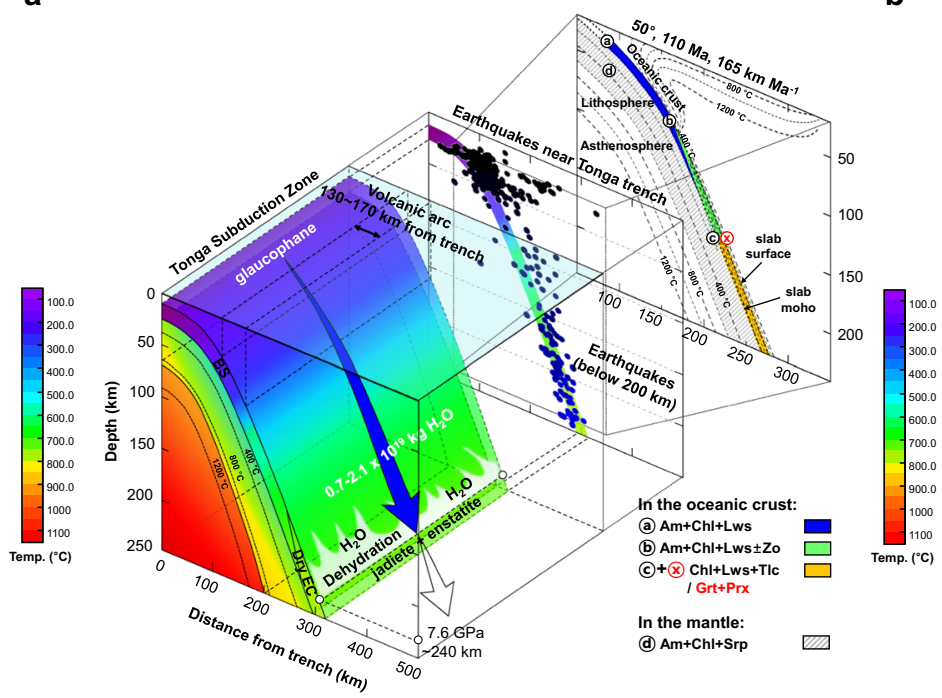

b

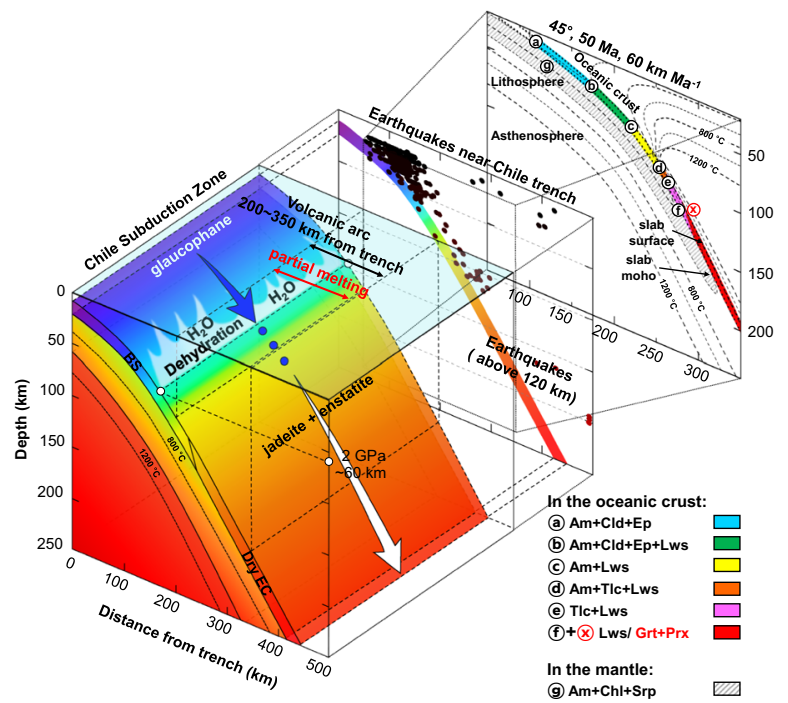

Fig. 4 Subduction models of glaucophane (amphibole) in the contemporary subduction settings. Subducting slab models representing a the Tonga (cold slabs) and $\mathbf{b}$ the Chile (warm slabs). The geometry and temperature profiles were adopted using the information available from the International Seismological Center (ISC-EHB) ${ }^{67-69}$ and the thermal models by Syracuse et al. ${ }^{19}$. Glaucophane remains stable along the cold subduction zone down to ca. $240 \mathrm{~km}$ depth (blue arrow), whereas it dehydrates and decomposes into jadeite and enstatite along the warm subduction zone between 50 and $100 \mathrm{~km}$ depths (white arrow). Based on experiments on a natural blueschist rock, the onset depth of dehydration breakdown is estimated to be $\sim 60 \mathrm{~km}$ depth. In the middle 2D projection layer, the earthquake frequencies are shown as filled circles using the data from the ISC-EHB. In the upper 2D projection layer, subducting hydrous minerals from Hacker et al. ${ }^{70}$ and Magni et al..$^{71}$ are shown in colors on each thermal model (slab dip, slab age, and convergence rate of $50^{\circ}, 110 \mathrm{Ma}, 165 \mathrm{~km} \mathrm{Ma}^{-1}$ for the cold slab and $45^{\circ}, 50 \mathrm{Ma}, 60^{\circ} \mathrm{C} \mathrm{km}^{-1}$ for the warm slab). Phase abbreviations: blueschist (BS), eclogite (EC), amphibole $(\mathrm{Am})$, chlorite $(\mathrm{Chl})$, chloritoid (Cld), lawsonite (Lws), epidote (Ep), zoisite (Zo), talc (Tlc), serpentine (Srp), garnet (Grt), and pyroxene (Prx).

with our observed stability of glaucophane under cold subduction conditions. On the other hand, glaucophane decomposes into pyroxenes. i.e., transition to eclogite, at shallower depths between 50 and $100 \mathrm{~km}$ in warm subduction zones with a geothermal gradient of $\sim 8-12{ }^{\circ} \mathrm{C} \mathrm{km}^{-1}$. Upon dehydration, hydroxyls of glaucophane are released to form aqueous fluid, which would migrate upward to induce partial melting of the overlying mantle wedge or cause the lowering of solidus temperature in the subducting slab itself ${ }^{43,44}$. We estimate the average $\mathrm{H}_{2} \mathrm{O}$ contents of glaucophane (and amphiboles) in the global oceanic crust to be in the range of $1.1-3.5 \times 10^{4} \mathrm{~g} \mathrm{H}_{2} \mathrm{O} \mathrm{m}^{-3}$ or $0.39-1.22 \mathrm{wt} \% \mathrm{H}_{2} \mathrm{O}$, which accounts for $7-20 \%$ of the total water content in the hydrated oceanic crust with overall 5-6 wt.\% $\mathrm{H}_{2} \mathrm{O}$ (Supplementary Table 4); such an amount, when released via dehydration reactions, would be sufficient to induce mantle melting and arc magmatism. In Fig. 4, we present the models of glaucophane stability together with the observed seismic frequencies and established mineral assemblages in two contrasting geothermal gradient settings. In cold subduction zones, glaucophane remains stable and enables water transport to deeper mantle. The amount of $\mathrm{H}_{2} \mathrm{O}$ transported by glaucophane in global cold subduction zones is estimated to be as much as ca. $0.7-2.1 \times 10^{19} \mathrm{~kg}$, which is approximately the amount of water in the Arctic ocean (Supplementary Table 4).

Our observation bears some implications for the distribution of seismic low-velocity layers, as well as seismic activities along the subducting slabs. According to our compressibility data (Supplementary Fig. 4), glaucophane behaves anisotropic even at high temperature, indicating strong mechanical resistance along the (100) plane, while [100] direction is relatively weak. Hydrous minerals have been suggested to be related to the seismic anisotropy and delayed seismic travel times along subduction zones in the depth range of $100-250 \mathrm{~km}$ (refs. ${ }^{45-52}$ ). The observed anisotropy and stability of glaucophane could, therefore, account for such seismic anomalies distributed, which would be deeper in the colder and older slabs than in the warmer and younger slabs ${ }^{53}$. Furthermore, seismic observations reveal that the low-velocity layers spatially coincide with the zones of intermediate-depth earthquakes ${ }^{54}$, which is in turn related to the dehydration of hydrous minerals ${ }^{45,55}$. With this regard, we show the correlation between the seismic frequencies along subduction zones and the stability range of glaucophane, i.e., the maximum depth of intraslab earthquakes ranges between 50 and $70 \mathrm{~km}$ in warm subduction zones, whereas it extends down to over $200 \mathrm{~km}$ in cold subduction zones ${ }^{56}$ (Fig. 4 and Supplementary Fig. 11). As dehydration embrittlement of serpentine was previously proposed as a possible mechanism for the intermediate-depth earthquakes ${ }^{23}$, subduction geotherm-dependent breakdown of glaucophane would provide another venue to explain the distribution of intermediate-depth earthquakes ${ }^{57-59}$. Our results would therefore serve as an experimental evidence to support the recent observation that the double seismic zone in the Tonga subduction system extends to deeper depths down to ca. $300 \mathrm{~km}$ (ref. ${ }^{60}$ ).

Among the 56 subduction geotherm data from Syracuse et al. ${ }^{19}$, we could categorize 16 subduction zones as cold subduction system on the basis of the thermal parameter with average values of $48.9^{\circ}, 119.7 \mathrm{Ma}, 74.8 \mathrm{~km} \mathrm{Ma}^{-1}$ for slab dip, age, and convergence rate, respectively (Supplementary Table 5 and Supplementary Fig. 10). Inferred from our results, sodic amphiboles, e.g., glaucophane, would be stable to deeper depths in ca. $28.5 \%$ of the global subduction system in the present Earth. Recent studies indicate that plate tectonics based on subductionrelated processes has been initiated during the Proterozoic eon ${ }^{2-6}$ or as early as 3.8 or $4.4 \mathrm{Ga}$ (refs. ${ }^{1,7}$ ), when the majority of subduction zones would be categorized as warm or intermediate-tohigh thermal gradients system ${ }^{3}$. According to our experimental results, the dehydration depth of glaucophane has increased with decreasing thermal gradients hence with secular cooling, which would translate to transportation of water into deeper Earth (Supplementary Table 4). We, therefore, conjecture that arc 
magmatism would have been more effective via ubiquitous transformation of blueschist to eclogite in the high thermal gradients system of the early Earth. As the Earth undergoes secular cooling, progressively colder subduction zones have emerged and resulted in ca. $28.5 \%$ of the whole subduction system in the present Earth. Consequently, arc magmatism, volcanism, and related seismic activities linked to the dehydration of amphiboles have been globally suppressed, enabling blueschist to persist and be preserved in today's geodynamic system. The "absence of blueschist" from the Precambrian rocks might thus be explained by the subduction geotherm-dependent dehydration of glaucophane. On the other hand, subduction efficiency, i.e., the proportional amount of subducted $\mathrm{H}_{2} \mathrm{O}$ passing through the subduction zone filter ${ }^{11}$, would have increased with the generation of low thermal gradients system toward the present Earth, as observed in our study.

\section{Data availability}

All data generated or analyzed during this study are included with this published article and its Supplementary Information.

Received: 10 June 2020; Accepted: 4 February 2021;

Published online: 05 March 2021

\section{References}

1. Furnes, H., de Wit, M., Staudigel, H., Rosing, M. \& Muehlenbachs, K. A vestige of Earth's oldest ophiolite. Science 315, 1704-1707 (2007)

2. Moyen, J. F., Stevens, G. \& Kisters, A. Record of mid-Archaean subduction from metamorphism in the Barberton terrain, South Africa. Nature $\mathbf{4 4 2}$, 559-562 (2006).

3. Brown, M. \& Johnson, T. Secular change in metamorphism and the onset of global plate tectonics. Am. Mineral. 103, 181 (2018).

4. Ganne, J. et al. Modern-style plate subduction preserved in the Palaeoproterozoic West African craton. Nat. Geosci. 5, 60 (2011).

5. Weller, O. M. \& St-Onge, M. R. Record of modern-style plate tectonics in the Palaeoproterozoic Trans-Hudson orogen. Nat. Geosci. 10, 305 (2017).

6. Stern, R. J. Evidence from ophiolites, blueschists, and ultrahigh-pressure metamorphic terranes that the modern episode of subduction tectonics began in Neoproterozoic time. Geology 33, 557-560 (2005).

7. Simon, T., Tracy, R., Mark, R. \& Jean-Francois, M. Heading down early on? Start of subduction on Earth. Geology 42, 139-142 (2014).

8. Herzberg, C. \& Gazel, E. Petrological evidence for secular cooling in mantle plumes. Nature 458, 619 (2009).

9. Herzberg, C., Condie, K. \& Korenaga, J. Thermal history of the Earth and its petrological expression. Earth Planet. Sci. Lett. 292, 79-88 (2010).

10. Zheng, Y., Chen, R., Xu, Z. \& Zhang, S. The transport of water in subduction zones. Sci. China Earth. Sci. 59, 651-682 (2016).

11. van Keken, P. E., Hacker, B. R., Syracuse, E. M. \& Abers, G. A. Subduction factory: 4. Depth-dependent flux of $\mathrm{H}_{2} \mathrm{O}$ from subducting slabs worldwide. $J$. Geophys. Res. Solid Earth 116, B01401 (2011).

12. Schmidt, M. W. \& Poli, S. in Treatise on Geochemistry 2nd edn (eds Holland, H. D. \& Turekian, K. K.) 669-701 (Elsevier, 2014).

13. Korenaga, J. Urey ratio and the structure and evolution of Earth's mantle. Rev. Geophys. 46, RG2007 (2008).

14. Ganne, J. \& Feng, X. Primary magmas and mantle temperatures through time. Geochem. Geophys. Geosyst. 18, 872-888 (2017).

15. Weller, M. B. \& Lenardic, A. On the evolution of terrestrial planets: bistability, stochastic effects, and the non-uniqueness of tectonic states. Geosci. Front. 9, 91-102 (2018).

16. Palin, R. M. et al. Secular change and the onset of plate tectonics on Earth. Earth Sci. Rev. 207, 103172 (2020).

17. Jackson, I. The Earth's Mantle: Composition, Structure, and Evolution (Cambridge University Press, 2000).

18. Grove, T. L., Chatterjee, N., Parman, S. W. \& Médard, E. The influence of $\mathrm{H}_{2} \mathrm{O}$ on mantle wedge melting. Earth Planet. Sci. Lett. 249, 74-89 (2006).

19. Syracuse, E. M., van Keken, P. E. \& Abers, G. A. The global range of subduction zone thermal models. Phys. Earth Planet. Inter. 183, 73-90 (2010).

20. Zheng, Y. F. \& Hermann, J. Geochemistry of continental subduction-zone fluids. Earth. Planets Space 66, 93 (2014).
21. Schmidt, M. W. \& Poli, S. Experimentally based water budgets for dehydrating slabs and consequences for arc magma generation. Earth Planet. Sci. Lett. 163, 361-379 (1998)

22. Pawley, A. R. \& Holloway, J. R. Water sources for subduction zone volcanism: new experimental constraints. Science 260, 664-667 (1993).

23. Jung, H., Green, H. W. II \& Dobrzhinetskaya, L. F. Intermediate-depth earthquake faulting by dehydration embrittlement with negative volume change. Nature 428, 545-549 (2004).

24. Ranero, C. R., Morgan, J. P., McIntosh, K. D. \& Reichert, C. J. Bending-related faulting and mantle serpentinization at the Middle America trench. Nature 425, 367-373 (2003).

25. Okazaki, K. \& Hirth, G. Dehydration of lawsonite could directly trigger earthquakes in subducting oceanic crust. Nature 530, 81-84 (2016).

26. Till, C. B., Grove, T. L. \& Withers, A. C. The beginnings of hydrous mantle wedge melting. Contrib. Mineral. Petrol. 163, 669-688 (2012).

27. Poli, S. The amphibolite-eclogite transformation; an experimental study on basalt. Am. J. Sci. 293, 1061-1107 (1993).

28. Maekawa, H., Shozul, M., Ishll, T., Fryer, P. \& Pearce, J. A. Blueschist metamorphism in an active subduction zone. Nature 364, 520-523 (1993).

29. Schmidt, M. W. \& Poli, S. The stability of lawsonite and zoisite at high pressures: experiments in CASH to $92 \mathrm{kbar}$ and implications for the presence of hydrous phases in subducted lithosphere. Earth Planet. Sci. Lett. 124, 105-118 (1994).

30. Peacock, S. M. The importance of blueschist $\rightarrow$ eclogite dehydration reactions in subducting oceanic crust. Geol. Soc. Am. Bull. 105, 684-694 (1993).

31. Ernst, W. Occurrence and mineralogic evolution of blueschist belts with time. Am. J. Sci. 272, 657-668 (1972).

32. Kono, Y., Irifune, T., Higo, Y., Inoue, T. \& Barnhoorn, A. P-V-T relation of $\mathrm{MgO}$ derived by simultaneous elastic wave velocity and in situ X-ray measurements: a new pressure scale for the mantle transition region. Phys. Earth Planet. Inter. 183, 196-211 (2010).

33. Carman, J. H. \& Gilbert, M. C. Experimental studies on glaucophane stability. Am. J. Sci. 283, 414-437 (1983).

34. Corona, J. C., Jenkins, D. M. \& Holland, T. J. Constraints on the upper pressure stability of blueschist facies metamorphism along the reaction: glaucophane $=$ talc +2 jadeite in the $\mathrm{Na}_{2} \mathrm{O}-\mathrm{MgO}-\mathrm{Al}_{2} \mathrm{O}_{3}-\mathrm{SiO}_{2}-\mathrm{H}_{2} \mathrm{O}$ system. Am. J. Sci. 313, 967-995 (2013).

35. Cheng, N., Jenkins, D. M. \& Huang, F. Dehydration of glaucophane in the system $\mathrm{Na}_{2} \mathrm{O}-\mathrm{MgO}-\mathrm{Al}_{2} \mathrm{O}_{3}-\mathrm{SiO}_{2}-\mathrm{H}_{2} \mathrm{O}$ and the effects of $\mathrm{NaCl}^{-}, \mathrm{CO}_{2}{ }^{-}$and silicate-bearing aqueous fluids. J. Petrol. 60, 2369-2386 (2020).

36. Comodi, P., Mellini, M., Ungaretti, L. \& Zanazzi, P. F. Compressibility and high pressure structure refinement of tremolite, pargasite and glaucophane. Eur. J. Mineral. 3, 485-500 (1991)

37. Jenkins, D. M., Corona, J. C., Bassett, W. A., Mibe, K. \& Wang, Z. Compressibility of synthetic glaucophane. Phys. Chem. Miner. 37, 219-226 (2010).

38. Holland, T. J. B. \& Powell, R. An internally consistent thermodynamic data set for phases of petrological interest. J. Metamorph. Geol. 16, 309-343 (1998).

39. Corona, J. C. \& Jenkins, D. M. An experimental investigation of the reaction: glaucophane +2 quartz $=2$ albite + talc. Eur. J. Mineral. 19, 147-158 (2007).

40. Holland, T. J. B. The reaction albite $=$ jadeite + quartz determined experimentally in the range $600-1200^{\circ} \mathrm{C}$. Am. Mineral. 65, 129-134 (1980).

41. Johnson, N. M. \& Fegley, B. Water on venus: new insights from tremolite decomposition. Icarus 146, 301-306 (2000).

42. Johnson, N. M. \& Fegley, B. Tremolite decomposition on Venus II. Products, kinetics, and mechanism. Icarus 164, 317-333 (2003).

43. Grove, T. L., Till, C. B. \& Krawczynski, M. J. The role of $\mathrm{H}_{2} \mathrm{O}$ in subduction zone magmatism. Annu. Rev. Earth. Planet. Sci. 40, 413-439 (2012).

44. Hirschmann, M., Asimow, P. D., Ghiorso, M. \& Stolper, E. Calculation of peridotite partial melting from thermodynamic models of minerals and melts. III. Controls on isobaric melt production and the effect of water on melt production. J. Petrol. 40, 831-851 (1999).

45. Abers, G. A. Seismic low-velocity layer at the top of subducting slabs: observations, predictions, and systematics. Phys. Earth Planet. Inter. 149, 7-29 (2005).

46. Abers, G. A. \& Sarker, G. Dispersion of regional body waves at $100-150 \mathrm{~km}$ depth beneath Alaska: in situ constraints on metamorphism of subducted crust. Geophys. Res. Lett. 23, 1171-1174 (1996).

47. Chantel, J., Mookherjee, M. \& Frost, D. J. The elasticity of lawsonite at high pressure and the origin of low velocity layers in subduction zones. Earth Planet. Sci. Lett. 349, 116-125 (2012).

48. Mainprice, D. \& Ildefonse, B. in Subduction Zone Geodynamics (eds Lallemand, S. \& Funiciello, F.) 63-84 (Springer, 2009).

49. Bezacier, L., Reynard, B., Bass, J. D., Wang, J. \& Mainprice, D. Elasticity of glaucophane, seismic velocities and anisotropy of the subducted oceanic crust. Tectonophysics 494, 201-210 (2010).

50. Mookherjee, M. \& Bezacier, L. The low velocity layer in subduction zone: structure and elasticity of glaucophane at high pressures. Phys. Earth Planet. Inter. 208, 50-58 (2012). 
51. Jung, H. Crystal preferred orientations of olivine, orthopyroxene, serpentine, chlorite, and amphibole, and implications for seismic anisotropy in subduction zones: a review. Geosci. J. 21, 985-1011 (2017).

52. Ha, Y., Jung, H. \& Raymond, L. A. Deformation fabrics of glaucophane schists and implications for seismic anisotropy: the importance of lattice preferred orientation of phengite. Int. Geol. Rev. 61, 720-737 (2019).

53. Wada, I. \& Wang, K. Common depth of slab-mantle decoupling: reconciling diversity and uniformity of subduction zones. Geochem. Geophys. Geosyst. 10, Q10009 (2009).

54. Hasegawa, A., Horiuchi, S. \& Umino, N. Seismic structure of the northeastern Japan convergent margin: a synthesis. J. Geophys. Res. Solid Earth 99 22295-22311 (1994)

55. Hacker, B. R., Peacock, S. M., Abers, G. A. \& Holloway, S. D. Subduction factory 2. Are intermediate-depth earthquakes in subducting slabs linked to metamorphic dehydration reactions? J. Geophys. Res. Solid Earth 108, 2030 (2003).

56. Peacock, S. M. \& Wang, K. Seismic consequences of warm versus cool subduction metamorphism: examples from Southwest and Northeast Japan. Science 286, 937-939 (1999).

57. Meade, C. \& Jeanloz, R. Deep-focus earthquakes and recycling of water into the Earth's mantle. Science 252, 68-72 (1991).

58. Kirby, S., Engdahl, R. E. \& Denlinger, R. Intermediate-depth intraslab earthquakes and arc volcanism as physical expressions of crustal and uppermost mantle metamorphism in subducting slabs. Geoph. Monog. Series 96, 195-214 (1996).

59. Nakajima, J., Tsuji, Y. \& Hasegawa, A. Seismic evidence for thermallycontrolled dehydration reaction in subducting oceanic crust. Geophys. Res. Lett. 36, L03303 (2009).

60. Wei, S. S., Wiens, D. A., van Keken, P. E. \& Cai, C. Slab temperature controls on the Tonga double seismic zone and slab mantle dehydration. Sci. Adv. 3, e1601755 (2017).

61. Boyd, F. R. \& England, J. L. The quartz-coesite transition. J. Geophys. Res. 65, 749-756 (1960).

62. Pawley, A. R. \& Wood, B. J. The high-pressure stability of talc and $10 \AA$ phase: Potential storage sites for $\mathrm{H}_{2} \mathrm{O}$ in subduction zones. Am. Mineral. 80 998-1003 (1995)

63. Jenkins, D. M., Holland, T. J. B. \& Clare, A. K. Experimental determination of the pressure-temperature stability field and thermochemical properties of synthetic tremolite. Am. Mineral. 76, 458-469 (1991)

64. Liou, J. G., Hacker, B. R. \& Zhang, R. Y. Into the forbidden zone. Science 287, 1215 (2000).

65. Le Bail, A., Duroy, H. \& Fourquet, J. L. Ab-initio structure determination of $\mathrm{LiSbWO}_{6}$ by X-ray powder diffraction. Mater. Res. Bull. 23, 447-452 (1988).

66. Le Bail, A. Whole powder pattern decomposition methods and applications: a retrospection. Powder Diffr. 20, 316-326 (2005).

67. Engdahl, E. R., van der Hilst, R. \& Buland, R. Global teleseismic earthquake relocation with improved travel times and procedures for depth determination. Bull. Seismol. Soc. Am. 88, 722-743 (1998).

68. Weston, J., Engdahl, E. R., Harris, J., Di Giacomo, D. \& Storchak, D. A. ISCEHB: reconstruction of a robust earthquake data set. Geophys. J. Int. 214 474-484 (2018).

69. Engdahl, E. R. et al. ISC-EHB 1964-2016, an improved data set for studies of earth structure and global seismicity. Earth Space Sci. 7, e2019EA000897 (2020).

70. Hacker, B. R., Abers, G. A. \& Peacock, S. M. Subduction factory 1. Theoretical mineralogy, densities, seismic wave speeds, and $\mathrm{H}_{2} \mathrm{O}$ contents. J. Geophys. Res. Solid Earth 108, 2029 (2003).

71. Magni, V., Bouilhol, P. \& van Hunen, J. Deep water recycling through time. Geochem. Geophys. Geosyst. 15, 4203-4216 (2014).

\section{Acknowledgements}

This work was supported by the Leader Researcher program (NRF-2018R1A3B1052042) of the Korean Ministry of Science and ICT (MSIT). We also thank the partial supports by NRF-2016K1A4A3914691, NRF-2019K1A3A7A09033395, and NRF-2020R1A2C2003765 grants of the MSIT. Synchrotron experiments were performed at the beamlines 3D and 5A at PLS-II, HPCAT and GSECARS at APS, and ECB P02.2 at PETRA-III. HPCAT operations are supported by DOE NNSA's Office of Experimental Sciences. GSECARS is supported by the NSF-Earth Sciences (EAR-1634415) and Department of Energy (DOE)GeoSciences (DE-FG02-94ER14466). The Advanced Photon Source is a U.S. Department of Energy (DOE) Office of Science User Facility operated for the DOE Office of Science by Argonne National Laboratory under Contract No. DE-AC02-06CH11357. We acknowledge DESY (Hamburg, Germany), a member of the Helmholtz Association HGF, for the provision of experimental facilities. H.C. thanks the support by the U.S. Department of Energy by the Lawrence Livermore National Laboratory under Contract No. DE-AC5207NA27344. The authors thank Xueyan Du and Yuyong Xiong at HPSTAR for assisting laser-heating experiment, Youmo Zhou and Toru Shinmei at Ehime University for multianvil press experiment, Guoyin Shen, Rostislav Hrubiak and Curtis Kenney-Benson at HPCAT for supporting Paris-Edinburgh Cell experiment, G. Diego Gatta at the University of Milan for providing a natural sample of jadeite, and Moonsup Cho at Chungbuk National University and Sang-Heon Dan Shim at Arizona State University for valuable discussions.

\section{Author contributions}

Y.B. contributed to the experiments and data analysis with the help from H.H, T.K., Y.P., C.P., D.P., V.P., and H.-P.L. Y.L. designed the research, discussed the results with H.C., H.J., L.W., T.I., and H.-K.M. and worked on the manuscript with all authors.

\section{Competing interests}

The authors declare no competing interests.

\section{Additional information}

Supplementary information The online version contains supplementary material available at https://doi.org/10.1038/s41467-021-21746-8.

Correspondence and requests for materials should be addressed to Y.L.

Reprints and permission information is available at http://www.nature.com/reprints

Publisher's note Springer Nature remains neutral with regard to jurisdictional claims in published maps and institutional affiliations. (c) Open Access This article is licensed under a Creative Commons
Attribution 4.0 International License, which permits use, sharing, adaptation, distribution and reproduction in any medium or format, as long as you give appropriate credit to the original author(s) and the source, provide a link to the Creative Commons license, and indicate if changes were made. The images or other third party material in this article are included in the article's Creative Commons license, unless indicated otherwise in a credit line to the material. If material is not included in the article's Creative Commons license and your intended use is not permitted by statutory regulation or exceeds the permitted use, you will need to obtain permission directly from the copyright holder. To view a copy of this license, visit http://creativecommons.org/ licenses/by/4.0/.

(C) The Author(s) 2021 